\title{
KAMPUNG TEMATIK SEBAGAI BENTUK PARTISIPASI MASYARAKAT DALAM PERMASALAHAN PERMUKIMAN KUMUH DI KOTA MALANG
}

\author{
Taufik Akbar') dan Faqih Alfian') \\ 1) dan 2) Program Studi Ilmu Politik; Fakultas Ilmu Sosial dan Ilmu Politik \\ Universitas Brawijaya Malang \\ Email: takbar@ub.ac.id
}

\begin{abstract}
Abstrak
Pemkot Malang mendukung gerakan universal akses sanitasi melalui program 100-0-100 (target 100\% akses air minum, 0\% kawasan permukiman kumuh, dan 100\% akses sanitasi layak). Salah satu program untuk mendukung kota tanpa kumuh (KOTAKU) di Kota Malang adalah pembangunan kampung-kampung tematik yang diharapkan sebagai pemecah masalah terkait permukiman kumuh yang ada. Pembangunan kampung tematik ini juga cenderung berorientasi pada pembangunan sektor perekonomian dan pariwisata Kota Malang. Penelitian ini bertujuan untuk mengetahui efektifitas pembangunan kampung tematik di Kota Malang sebagai upaya untuk menanggulangi permasalahan pembangunan wilayah di Kota Malang. Penelitian ini menggunakan pendekatan deskriptif kualitatif untuk menyelidiki, menemukan, menggambarkan serta menjelaskan kondisi sesungguhnya yang terjadi di masyarakat. Lokasi penelitian adalah kawasan kampung tematik yang berada di Kota Malang. Dimana kawasan tersebut dipilih, karena merupakan kampung tematik pertama yang lahir dari perkampungan kumuh. Kawasan tersebut telah mengalami pembenahan dan upgrading, sehingga menjadi lebih layak huni. Hasil penelitian menunjukkan bahwa pengaruh pembangunan kampung tematik dalam upaya menanggulangi permasalahan pembangunan wilayah perkotaan di Kota Malang memberikan dampak yang sangat positif guna penanganan mengenai pembangunan wilayah Kota Malang. Hal tersebut dapat dilihat dari bagaimana indikator world bank akan pemukiman tidak layak yang tidak bisa disematkan lagi pada kampung-kampung tematik tersebut.
\end{abstract}

Kata kunci: Kampung Tematik, Kota Malang, Partisipasi Masyarakat, Permukiman Kumuh.

\begin{abstract}
Malang City Government supports the universal access sanitation through a 100-0-100 program (target of $100 \%$ access to drinking water, 0\% of slum areas, and $100 \%$ of access to proper sanitation). One program to support cities without slums (KOTAKU) in Malang City is the development of thematic villages that are expected to be problem solvers related to existing slums. The development of this thematic village also tends to be oriented towards the development of the economy and tourism sector in Malang City. This study aims to determine the effectiveness of the development of thematic villages in Malang City as an effort to overcome the problems of regional development in Malang City. This study uses a qualitative descriptive approach to investigate, discover, describe and explain the real conditions that occur in society. The research location is a thematic village area located in Malang City. Where the area was chosen, because it is the first thematic village born from slums. The area has undergone revamping and upgrading, making it more livable. The results showed that the influence of the development of thematic villages in an effort to overcome the problems of urban development in the city of Malang had a very positive impact in handling the development of the city of Malang. This is as we can see from how the world bank indicator of unfit settlements or slum area that cannot be pinned again in these thematic villages.
\end{abstract}

Keywords: Community Participation, Malang City, Slum Settlement, Thematic Village.

\section{PENDAHULUAN}

Kota akan mengalami perkembangan dan pertumbuhan, tidak hanya pertumbuhan secara ekonomi, namun juga pertumbuhan penduduk. Pertumbuhan penduduk merupakan faktor dominan yang membawa banyak 
perubahan pada kondisi internal kota, karena tingginya jumlah penduduk akan berpengaruh pada semakin terbatasnya lahan kota dan berdampak pada permukiman menjadi kumuh. Permukiman kumuh pada umumnya disebabkan oleh tingginya tingkat kepadatan penduduk dan kebutuhan akan permukiman yang tinggi. Hal ini dapat menyebabkan beberapa persoalan lain yang juga ikut timbul ke permukaan, diantara lainnya adalah kemiskinan, sanitasi, dan masalah lingkungan (Farida, 2016). Dengan terbatasnya lahan di perkotaan maka masyarakat akan memanfaatkan lahan-lahan seperti bantaran sungai, dekat rel kereta api dan tempat-tempat yang seharusnya tidak boleh dimanfaatkan untuk membangun rumah.

Permukiman kumuh adalah permukiman yang tidak layak huni karena ketidakteraturan bangunan, tingkat kepadatan bangunan yang tinggi, dan kualitas bangunan serta sarana dan prasarana yang tidak memenuhi syarat (Peraturan Pemerintah, 2016). Permukiman ini secara umum mempunyai kondisi sosial ekonomi rendah, dan prasarana lingkungan hampir tidak ada atau tidak memenuhi persyaratan teknis dan kesehatan. Dengan adanya permukiman kumuh, juga memberikan citra buruk yaitu ketidakberdayaan dan ketidakmampuan pemerintah dalam pengaturan pelayanan kebutuhan hidup dan penghidupan warganya.

Kota Malang merupakan kota yang dapat dikatakan sebagai kota yang padat penduduk yang secara terus menerus mengalami perkembangan dan pertumbuhan. Hal ini dikarenakan Kota Malang merupakan salah satu Kota di Jawa Timur yang juga menjadi pusat perekonomian serta wilayah dengan total jumlah penduduk sebanyak 895,387 jiwa per tahun 2017. Kota Malang juga merupakan Kota yang memiliki posisi cukup strategis di Provinsi Jawa Timur yaitu sebagai kota terbesar kedua setelah Kota Surabaya dan mempunyai perkembangan yang cepat. Dalam perkembangannya, Kota Malang terkenal dengan salah satu konsep perencanaan kota kreatif yang dapat dilihat melalui kreatifitas dalam pembangunan perkampungan (Kamalita, 2017). Wilayah perkampungan di
Kota Malang juga bisa dikatakan sebagai ruang kreatif kota malang yang dapat menjadi pusat kegiatan dan perekonomian kreatif sebagai pemecah permasalahan permukiman kumuh. keberadaraan kampung menjadi pondasi dalam struktur perkembangan Kota Malang dan juga mempunyai peran dalam perekonomian kota (Zuhrya, 2017).

Pada tahun 2015, disebutkan luas kawasan kumuh di Kota Malang sesuai dengan Surat Keputusan Walikota Malang Nomor 188.45/86/35.73.112/2015 tahun 2015 mencapai 608,6 Ha. Wilayah dengan kawasan kumuh terluas berada di Bareng $(81,56 \mathrm{Ha})$; disusul Ciptomulyo (62,6 Ha); Penanggungan (53,01 Ha); dan Kasin (48,20 Ha). Sementara jika dirinci per kecamatan, kawasan kumuh terbanyak terdapat di Kecamatan Klojen (346,51 Ha); Sukun (132,8 Ha); Kedungkandang (72,9 Ha); Lowokwaru (31,35 Ha); dan Blimbing (25,04 Ha).

Untuk mewujudkan kota tanpa kumuh, Pemkot Malang meluncurkan program 100-0100 yang artinya target 100 persen akses air minum, nol persen kawasan permukiman kumuh, dan 100 persen akses sanitasi layak. Salah satu pembangunan perkampungan dan penataan permukiman kumuh di Kota Malang yang terkenal dapat dilihat melalui pembangunan kampung tematik. Pembangunan kampung tematik merupakan upaya pemerintah dalam mengatasi permukiman kumuh di beberapa sudut kota Malang. Dikutip melalui Malang-Post (Arifin, 2018) bahwa Walikota Malang, H. Moh. Anton menyampaikan salah satu mindset pembangunan kampung-kampung tematik di sekitar wilayah Daerah Aliran Sungai (DAS) adalah paradigma baru Pemkot Malang, yang ingin menjadikan permukiman di zona rawan tersebut sebagai salah satu etalase pembangunan Kota Malang. Kampung Wisata Jodipan (KWJ), Kampung Tridi di Purwantoro, maupun Kampung Putih di Kelurahan Klojen, kini bisa dikatakan telah bertransformasi sebagai etalase dimaksud. Berbasis ide dan aspirasi masyarakat setempat, "etalase-etalase pembangunan" baru terus dikatalisasi dan diwujudkan oleh Pemkot Malang. 
Salah satu pembangunan kampung tematik yang menuai keberhasilan dalam penanggulangan permukiman kumuh terjadi di Semarang. Dilansir melalui Jawa Pos (Pratono, 2017) bahwa Pemerintah Kota Semarang telah merampungkan pembangunan 133 Kampung Tematik di 16 kecamatan. Pemerintah Kota Semarang tidak hanya menuai keberhasilan mengubah permukiman kumuh menjadi lebih tertata, tetapi juga berhasil mendorong perubahan sosial dan peningkatan ekonomi di wilayah perkampungan tersebut (Nursyahbani dan Pigawati, 2015). Kota Semarang hanya menyisakan angka kemiskinan sebesar 4,85\% (Sabaris, 2018).

Salah satu contoh dari permukiman kawasan kumuh terdapat di beberapa Kelurahan Malang. Kawasan tersebut tergolong kedalam kategori kumuh sedang, dengan permasalahan utama kawasan kumuh ini adalah kondisi fisik hunian, sanitasi, drainase, kepadatan penduduk, dan kepadatan lingkungan. Adanya kawasan permukiman kumuh ini menjadi satu bentuk atau kegagalan Kota Malang dalam menyediakan rumah yang layak bagi seluruh golongan penduduk.

Kebijakan pemerintah di Kota Malang dalam penataan permukiman kumuh tertuang dalam Peraturan Daerah Nomor 7 Tahun 2001 Tentang Rencana Tata Ruang Wilayah (RTRW) Kota Malang Tahun 2001-2011. Berdasarkan RTRW Kota Malang 2001-2011 menyatakan bahwa kebijakan pemerintah Kota Malang dalam penataan permukiman kumuh antara lain pertama, pembangunan prasarana di permukiman kumuh. Kedua, penataan permukiman di sekitar Daerah Aliran Sungai (DAS) melalui pemindahan penduduk ke daerah lain, bagi penduduk yang berada di wilayah sempadan sungai 15 meter. Ketiga, penataan permukiman di sempadan rel kereta api melalui relokasi dan perbaikan lahan sempadan rel kereta api.

Pembangunan kampung-kampung tematik di Kota Malang pada umumnya diharapkan sebagai pemecah masalah terkait permukiman kumuh yang ada. Pembangunan kampung tematik ini juga cenderung berorientasi pada pembangunan sektor perekonomian dan pariwisata Kota Malang. Seperti yang disampaikan oleh walikota non-aktif Kota Malang H. Moch Anton "Terobosan dan solusi dari implementasi kreativitas seperti di Kampung Warna Warni Jodipan ini dapat memberikan dampak positif. Tidak saja bagi pertumbuhan perekonomian, tetapi juga membawa tren positif bagi manajemen pengelolaan Kota Kreatif sehingga dapat mengakselerasi pencapaian pembangunan berkelanjutan".

Pengembangan Kota Kreatif juga diharapkan dapat mendorong pemerataan pembangunan daerah melalui percepatan pertumbuhan pusat-pusat perekonomian dengan menggali potensi dan keunggulan daerah. Karena dengan berbasis pada potensi lokal sebagai keunggulan dan identitas dasar, maka secara efektif dapat meningkatkan nilai tambah dan daya saing (https://malangkota.go.id/2016/09/05/kampun g-warna-warni-jadi-ikon-wisata-baru-kotamalang/ tanggal 24 april 2018 pukul 17.00).

Pembangunan kampung tematik ini juga menjadi salah satu solusi untuk meningkatkan partisipasi dan memunculkan inisiatif masyarakat dalam pembangunan. Pembangunan kampung tematik pada umunya menghadirkan corak dan nilai estetika yang berbeda dengan mengusung kelestarian lingkungan sekaligus pengembangan ekonomi kreatif. Penelitian ini bertujuan untuk mengetahui efektifitas pembangunan kampung tematik di Kota Malang sebagai upaya untuk menanggulangi permasalahan pembangunan wilayah di Kota Malang.

\section{METODE PENELITIAN}

Penelitian ini bersifat deskriptif kualitatif dengan meneliti status sekelompok manusia, suatu objek dengan tujuan membuat deskriptif, gambaran atau lukisan secara sistematis, faktual dan akurat mengenai faktafakta atau fenomena yang diselidiki. Lokasi penelitian adalah di kawasan kampung tematik Jodipan yang berada di Kota Malang. Dimana kawasan tersebut dipilih, karena merupakan kampung tematik pertama yang lahir dari perkampungan kumuh. Kawasan 
tersebut telah mengalami pembenahan dan upgrading, sehingga menjadi lebih layak huni.

Teknik pengumpulan data didapatkan dari data primer dan sekunder. Data primer didapatkan wawancara dilakukan sebagai upaya mendekatkan informasi dengan cara bertanya langsung kepada informan. Adapun wawancara yang dilakukan adalah wawancara tidak berstruktur, dimana di dalam metode ini memungkinkan pertanyaan berlangsung luwes, arah pertanyaan lebih terbuka, tetap fokus, sehingga diperoleh informasi yang kaya dan pembicaraan tidak kaku. Wawancara dilakukan kepada warga sekitar dengan cara random sampling dan penjaga tiket masuk kampung tematik sebagai yang merasakan manfaat langsung dari kampung tematik yang akan di teliti ini. Selain wawancara juga melakukan observasi secara langsung. Observasi langsung adalah cara pengumpulan data dengan cara melakukan pencatatan secara cermat dan sistematik. Dengan observasi secara langsung, dapat memahami konteks data dalam berbagai situasi, maksudnya dapat memperoleh pandangan secara menyeluruh.

Teknik analisis data mencakup reduksi data (data reduction), penyajian data (data display), dan kesimpulan atau verifikasi (conclusion drawing). Mereduksi data berarti merangkum, memilih hal-hal yang pokok, memfokuskan pada hal-hal yang penting, dicari tema dan polanya. Penyajian data bisa dilakukan dalam bentuk uraian singkat, bagan, hubungan antar kategori, flowchart dan sejenisnya. Dengan mendisplay data maka akan memudahkan untuk memahami apa yang terjadi, merencanakan kerja selanjutnya berdasarkan apa yang telah dipahami tersebut karena metode yang digunakan dalam penelitian ini adalah studi kasus, maka display data yang dilakukan lebih banyak dituangkan ke dalam uraian. Kesimpulan dalam penelitian kualitatif mungkin dapat menjawab rumusan masalah yang dirumuskan sejak awal, tetapi mungkin juga tidak, karena masalah dan rumusan masalah dalam penelitian kualitatif masih bersifat sementara dan akan berkembang setelah peneliti berada di lapangan.

\section{HASIL DAN PEMBAHASAN Kampung Tematik Kota Malang}

Kampung Tematik di Kota Malang pada awalnya bermula di kawasan kumuh yang berada di bantaran sungai Kota Malang. Kampung kumuh pertama yang menjadi kampung tematik adalah kampung warnawarni yang berada di Kelurahan Jodipan. Kampung yang berdapat di wilayah Kelurahan Jodipan yang di Kota Malang kini telah berubah wajahnya menjadi kampung warna-warni. Dahulu sebelum tahun 2016 merupakan sebuah kawasan kumuh yang padat penduduk. Saat ini di Kota Malang sendiri terdapat berbagai macam kampung tematik dan hal ini berawal dari sebuah proyek mahasiswa untuk mengubah wajah sebuah kampung kumuh dipinggiran sungai Kota Malang. Mengubah wajah sebuah kampung kumuh ternyata tidak hanya memberikan perubahan secara fisik suatu wilayah tapi saat ini hal tersebut seolah menjelma menjadi sebuah solusi guna memcahkan permasakan mengenai permukiman kumuh di areal perkotaan.

Keunikan setiap kampung-kampung tematik yang ada di Kota Malang membuat para wisatawan pun berduyun-duyun datang, baik dari dalam kota atau pun luar kota datang untuk melihat keunikan kampung tematik yang ada di Kota Malang. Bahkan hingga wisatawan manca negara pun berduyun-duyun datang melihat kampungkampung tematik yang ada. Kini kampungkampung kumuh yang telah berubah menjadi kampung tematik telah mendapatkan berbagai manfaat serta apresiasi bahkan salah satu kampung tematik yaitu kampung warna-warni di Jodipan telah mandapat pengesahan dari pemerintah Kota Malang. Hal ini justru berbanding terbaik dari kondisi kampung yang sebenarnya illegal.

Memang tidak semua bangunan yang ada di kampung-kampung tematik bersifat illegal, beberapa bangunan dan tanah telah memiliki surat tanak petok D dari jaman kolonial belanda. Namun, bahkan surat ini pun kini telah dianggap memiliki kekuatan yang lemah dibandingkan dengan surat tanah yang lebih umum berlaku saat ini yaitu sertifikat hak 
milik. Hal ini telah diatur dalam "UU Nomor 5 Tahun 1960 Tentang Peraturan Dasar Pokok-Pokok Agraria pasal 20 ayat 1 menyebutkan bahwa Hak milik adalah hak turun-menurun, terkuat dan terpenuh yang dapat dipunyai orang atas tanah, dengan mengingat ketentuan dalam pasal 6". Melalui undang-undang tersebut dapat dinyatakan bahwa hanya yang memiliki sertifikat hak milik atas suatu tanah lah yang dapat dianggap memiliki tanah tersebut. Sehingga dari hal ini dapat dikatakan mayoritas yang menempati permukiman-permukiman kumuh tersebut merupakan hal illegal, ada pun yang memiliki hak atas tanah tersebut namun lemah dasar hukumnya.

\section{Dampak Kampung Tematik}

Latar belakang orang-orang yang menghuni kampung-kampung kumuh yang kini berubah menjadi kampung tematik di Kota Malang sangatlah beragam. Namun, seluruhnya memiliki satu kesamaan yaitu himpitan ekonomi serta desakan kebutuhan untuk memiliki tempat tinggal membuat orang-orang tersebut menempati tanah-tanah illegal milik pemerintah. Guna dapat tinggal di kampung-kampung tematik yang dulunya adalah kampung kumuh cukup dengan mengurus surat keterangan domisili tempat tinggal ke pihak RT/RW setempat. Hal ini diungkapkan oleh seorang warga yang miliki petok D di kawasan kampung wisata sebagai berikut:

"...Memang bangunan-bangunan disini kebanyakan tidak ada surat-suratnya. Kalau mau tinggal disini biasanya orang-orang cuma tinggal mengurus surat-surat ke RT/RW setempat saja... “

Pernyataan yang disampaikan diatas memberikan sebuah gamabaran bahwa kemungkikanan untuk semakin meluasnya perkampungan serta permukimanpermukiman kumuuh di Kota Malang masih bisa terus bertambah. Namun kini dengan berubahnya permukiman-permukiman kumuh di Kota Malang menjadi kampung tematik seolah manjadi sebuah pemecahan masalah dalam pembangunan wilayah perkotaan.
Begitu besarnya animo wisatawan untuk datang membawa manfaat tersendiri bagi masyarakat sekitar. Sehingga dari hal ini memunculkan inisiatif dan pastisipatif masyarakat untuk dapat berkembang guna menyokong aspek-aspek kedidupannya yang dahulu berada pada taraf minimum sekaligus mendorong meningkatnya aspek-aspek ketahanan suatu kota sehingga dari hal ini akan berdampak pada penanggulangan permasalahan mengenai pembangunan wilayah perkotaan di Kota Malang. Aspekaspek serta dampak yang dihasilkan dari berubahnya kawasan kumuh menjadi kampung tematik yang ada di Kota Malang disajikan sebagai berikut:

\section{a. Ekonomi}

Pertama aspek yang paling berdampak dengan berubahnya sebuah kampung kumuh yang ada di Kota Malang menjadi kampung-kampung tematik adalah pada segi perekonomian. Pada hari biasa, wisatawan yang datang bisa mencapai ratusan dan akan lebih meledak lagi ketika musim liburan sekolah tiba, membuat peluang usaha terbuka lebar di kampungkampung tematik di kota malang. Dari tingginya animo wisatawan untuk mengunjingi kota akhirnya memicu untuk berkembangnya perekonomian kreatif dan memicu berkembangnya perekonomian mikro masyarakat sekitar. Dimulai dari hal kecil seperti dibukanya lahan-lahan parkir untuk wisatawan, toko-toko yang menjual kebutuhan dasar dan pokok, warung makan, sampai dengan dibuatnya suvenir untuk menjadi oleh-oleh para wisatawan semuanya berjalan sehingga dapat meningkatkan perkonomian masyarakat sekitar. Bergeraknya sektor-sektor perekonomian kecil masyarakat yang ada di kampung-kampung tematik ini membuat tenaga kerja yang sebelumnya menanggur dapat terserap dengan baik. Hal ini pula yang disampaikan oleh warga sekitar kepada peneliti sebagai berikut:

“...Sejak berubahnya kampung ini menjadi kampung tematik (kampung 3D) kondisi masyarakat sekarang jadi jauh lebih baik. Dulu sebelum menjadi kampung tematik 
seperti sekarang sangat banyak yang menganggur disini tapi sekarang sejak menajadi kampung tematik semuanya jadi bisa bekerja. Pemuda-pemuda disini yang masih menganggur ada yang dipekerjakan menjadi tukang parkir, ada yang pekerjakan untuk mengarap spot-spot foto baru, ada yang dipekerjakan di paguyupan juga dan lain sebagainya. Bahkan ibu-ibu disekitar sini juga bisa ikut bekerja dengan membuat suvenir-suvenir untuk oleh-oleh para wisatawan yang berkunjung disini...".

Berdasarkan pada penjelasan diatas dapat dilihat bahwa keadaan kampung yang dulunya kumuh kemudian berubah menjadi sebuah kampung tematik dapat menajadi sebauh terobosan dalam mengatasi permasalahan yang ada di kampung-kampung kumuh yang mana dalam hal ini adalah pada bidang perekonomian masyarakat kecil. Terserapnya pengangguran dengan berubahnya kampung kumuh menjadi kampung tematik ini tentu memberikan dampak yg cukup baik bagi Kota Malang itu sendiri, mengingat angka pengangguran kota malang sangatlah tinggi yang bahkan pada waktu tahun 2015 sempat menempati Kota dengan angka pengangguran tertinggi kedua di Jawa Timur setelah Kota Kediri.

Pada mulanya seperti yang disampaikan diatas kampung tematik yang ada di Kota Malang berawal dari proyek mahasiswa yang diaplikasikan di salah satu kampung yang ada di wilayah Kelurahan Jodipan. Dari hal ini mematik keinginan warga kampung sekitar yang lain untuk ikut menjadikan kampunya menajadi kampung tematik. Berangkat dari hal ini perkampungan tematik yang ada di Kota Malang berkembang sehingga berdampak peningkatan aspek pereknomian masyarakat yang ada di wilayah perkampungan tematik yang ada di Kota Malang itu sendiri. Berbeda dengan perkampungan tematik yang ada di jodipan, perkampungan-perkampungan lain selain yang ada di jodipan dimulai dari inisiatif dan keinginan masyarakat itu sendiri tanpa ada bantuan dari pihak manapun termasuk pemerintah. Sehingga seluruh perekonomian yang berputar di wilayah kampung-kampung tematik tersebut berasal dari masyarakat dan kembali dipergunakan untuk kesejahteraan masyarakat.

Melihat lebih jauh mengenai naiknya angka perekonomian dan kesejahteraan masrakat yang menghuni kampungkampung tematik yang ada di Kota Malang dapat dilihat melalui berkembangnya perekonomian mikro masyarakat tematik Kota Malang. Hal tersebut ditunjukkan maraknya di buka toko-toko yang menjual kebutuhan pokok seperti sembako dan lain sebagainya. Penduduk yang menghuni kampung tematik di Kota Malang dapat melihat adanya pasar yang besar dari banyaknya wisatawan yang berkunjung sehingga memberanikan diri untuk membuka usaha. Hal ini juga sebagai salah satu faktor yang dapat mengurangi pengangguran yang ada di perkampungan kumuh di Kota Malang. Hal ini diketahui melalui wawancara yang dilakukan peneliti dengan salah seorang pemilik kios toko sebagai berikut:

“...Yah alhamdulillah sekali sekarang mas. Dulu yang kerja Cuma bapak. Anak juga baru lulus sekolah jadi masih kerja serabutan tapi sejak jadi seperti sekarang jadi banyak pemasukan. Kan bisa dilihat ini ramai mas, orang dari mana-mana datang. Akhirnya kami (sekeluarga) beranikan buka toko dengan modal seadanya. Akhirnya yah alhamdulillah pendapatan keluarga juga meningkat, terus anak juga ikut kerja perkir di depan...".

Pernyataan diatas memberikan gambaran bahwa perekenomian masyarakat sejak berubahnya kampung kumuh menjadi kampung tematik memberikan dampak yang cukup signifikan pada perekonomian masyarakat yang tinggal di kampung tematik. Selain dari toko-toko penjual kebutuhan pokok, ada juga warung-warung makan yang dibuka di kampung-kampung tematik Kota 
Malang. Wisatawan yang datang melancong tentu membutuhkan makanan dengan dibukanya tempat-tempat menjual makan tentu para wisatawan tidak akan kesulitan untuk mencari makan dan hal ini lah yang menjadi peluang pasar yang di manfaatkan oleh masyarakat.

Seluruh aspek perekonomian yang ada di kampung-kampung tematik di Kota Malang kecuali yang berasal dari modal pribadi akan dikelola oleh paguyupanpaguyupan yang ada di kampung-kampung tematik setempat. Sehingga dapat dikatakan bahwa masyarakat yang ada ada di kampung-kampung tematik yang dulunya merupakan kampung kumuh telah mengembangkan ketahanan ekonomi mereka sendiri secara mandiri tanpa ada campur tangan pemerintah.

\section{b. Sosial}

Kondisi sosial yang ada di kampungkampung kumuh yang kini telah berubah menjadi kampung tematik yang ada di Kota Malang kini telah jauh berubah. Hal ini tentu juga merupakan dampak dari kondisi kampung yang dahulunya kumuh kemudian menjadi sebuah pariwisata. Hal ini tuturkan oleh para warga yang di temui peneliti ketika berada di kampung tridi, sebegai berikut:

“...Dulu disini orangnya seram-seram mas, suka ribut juga kampung sini sama kampung sana (jodipan). Tapi sekarang sudah berubah mas, sudah guyup, sudah rukun. Malu juga mas dilihat orang soalnya sekarang kan disini sudah jadi tempat pariwisata, semua orang tahu tempat ini bahkan sampai ke luar negeri. Jadi yah orang-orang disini sudah pada tobat, tidak seperti dulu lagi...”.

Berdasarkan pada penuturan diatas dapat dilihat bahwa dulu kampungkampung tematik ketika masih memiliki label kawasan-kawasan kumuh yang ada di Kota Malang sering sekali terjadi permusnahan atau benturan sosial antara satu kelompok warga dengan kelompok warga yang lain. Hal ini tentu membuat situasi dan kondisi di kampung-kampung tersebut menjadi mencekam dan tidak kondusif. Hal ini sesuai dengan salah satu ciri-ciri yang disebutkan oleh UNHABITAT yakni keadaan harta benda yang tidak aman. Hal ini sebenarnya merujuk pada kondisi lingkungan yang tidak aman di kawasan kumuh.

Lebih jauh lagi mengkaji mengenai kondisi sosial suatu daerah di perkotaan. Ketika kondisi pada suatu masyarakat telah berubah mencekam dan tidak kondusif maka hal tersebut pasti akan menyebabkan keresahan, dan dengan didukung dengan cepatnya isu menyebar pada era saat ini maka keresahan tersebut akan menyebabkan kekacauan pada seluruh kota. Tapi hal ini sudah tidak lagi terjadi dan tercegah akibat berubahnya kondisi perkampungan-perkampungan kumuh di Kota Malang. Melihat kondisi sosial perkampungan-perkampungan kumuh yang ada di Kota Malang juga dapat dilihat melalui tingkat pendidikan yang diperoleh oleh masyarakat yang tinggal disana.

Membicakan mengenai tingkat pendidikan, setidaknya seluruh masyarakat yang terdata sebagai warga Kota Malang yang tinggal di kawasan kumuh telah mengenyam pendidikan hingga SMP. Hal tersebut ditunjukkan pada dengan data yang ada pada tingkat partisipasi sekolah di Kota Malang pada tahun 2015-2016 pada usia 7-15 yang tidak/belum pernah sekolah kosong, yang artinya saat ini seluruh penduduk berusia 7-15 telah mengenyam pendidikan hingga taraf SMP. Sehingga dapat disimpulkan bahwa kondisi pendidikan warga yang tinggal di kawasan-kawasan kumuh di Kota Malang telah mengenyam pendidikan yang cukup berdasar pada data tidak adanya warga Kota Malang yang tidak pernah mengeyam pendidikan di usia 7-15 tahun. Tidak dapat dipungkiri bahwa tingkat pendidikan juga mempengaruhi dampak yang dihasilkan dari inisiatif serta partisipasi dalam suatu hal yang dilakukan oleh masyarakat itu sendiri. Karenanya pendidikan menjadi sebuah hal yang berharga dimasa kini. 


\section{c. Lingkungan}

Kondisi lingkungan perkampungan kumuh seperti pada umumnya sudah pasti konidisi ruang, sanitasi, pengelolaan sampah dan lain sebagainya berada pada taraf-taraf yang minim bahkan kurang. Terutama mengenai kondisi kebersihan yang ada diarea kawasan kumuh cenderung sama sekali jauh dari kata bersih. Kondisi lingkungan yang kotor tentu akan berpengaruh pada kondisi kesehatan masyarakat yang hidup di lingkunan tersebut. Lebih buruk lagi jika sampai ada penumpukkan sampah, jika sampai terjadi penumpukkan sampahsampah hingga berserakan hingga sampai pada areal sungai maka hal tersebut akan meningkatkan resiko banjir di perkotaan semakin besar. Namun semua kondisi diatas seolah berubah derastis ketika permukiman-permukiman kumuh yang ada di Kota Malang berubah menjadi kampung tematik. Dari hal ini menimbulkan kesadaran bagi masyarakat yang menghuni kampung-kampung tematik untuk melakukan pengelolaan sampah terutama yang berada di bantaran sungai. Hal ini didapatkan peneliti melaui penurutan warga yang mengehuni kampung 3D sebagai berikut :

"......Wah dulu yah sungai enggak sebersih ini mas. Dulu masih banyak sampah-sampah tapi sekarang kan sudah jadi wisata jadi yah malu kalau kotor. Akhirnya warga gotong royong buat membersihkan sungai di sepanjang kawasan wisata ini...”.

Berubahnya wujud kampung kumuh menjadi kampung tematik memberikan dampak yang cukup signifikan bagi kehidupan masyarkat yang tinggal didalamnya. Bahkan tidak hanya melakukan pengelolaan sampah yang ada di sungai, masyarakat yang tinggal di kampung-kampung tematik bahkan kini telah sadar betul akan kondisi lingkungan di kawasan permukiman yang mereka tempati. Hal tersbut diungkapkan oleh salah satu warga yang menghuni kampung tematik sebagai berikut:
“...Sekarang yah tiap sore dibersihkan sama ibu-ibu pkk mas, makanya lingkungannya bersih. Kalau tidak seperti itu yah kotor mas soalnya kan banyak orang yang datang kesini. Selain itu yah kan disini dukunjungi banyak orang jadi kan gak enak dilihat juga kalau kotor...".

Tidak hanya dari segi ekonomi tapi juga segi sosial serta segi lingkungan turut berubah menjadi lebih baik dengan berubahnya wujud fisik dari permukiman kumuh yang ada. Dari penuturan diatas memberikan gambaran bahwa berubahnya kampung kumuh menjadi kampung tematik menjadikan inisiatif masyarakat semakin meningkat dalam bidang lingkungan. Hal ini tentu merupakan langkah yang positif bagi keadaan masyarakat yang tinggal dikawasan kumuh dan sekitarnya.

\section{d. Infrastruktur}

Membicarakan mengenai pengaruh pembangunan kampung tematik tentu tidak akan terlepas dari hal yang paling mendasar yakni infrastruktur. Permukiman-permukiman kumuh yang ada di Kota Malang dahulu sebelum menjadi kampung tematik mayoritas sudah berisi bangunan-bangunan semi-permanen maupun permanen yang di bangun seadanya untuk tempat tinggal. Sehingga dari hal ini memunculkan kesan sangat padat akibat penataan ruang yang sembarangan menyebabkan satu bangunan dengan bangunan lain sangat berhimpitan satu sama lain. Banyaknya jumlah rumah yang saling sama lain menyebabkan kesan kumuh karena sangat padatnya permukiman yang ada di satu wilayah yang kecil.

Hal ini tentu sangat sulit dirubah mengingat jumlah rumah, masyarakat yang tinggal, kontur wilayah serta ruang yang tidak memadai menajadikan kesan kumuh pada wilayah Kota Malang amat sangat sulit untuk diatasi. Perlu diketahui pula bahwa wilayah Kota Malang sendiri merupakan daerah pegunungan yang memiliki kontur tanah tidak merata sehingga menyebabkan penataan ruang 
menjadi amat sangat sulit di perkampungan-perkampungan kumuh di Kota Malang yang mayoritas menempati daerah-daerah yang memiliki kemiringan lumayan tinggi seperti di bantaran sungai.

Merubah kondisi kumuh yang ada di Kota Malang memang sangatlah sulit bahkan hampir mustahil untuk dilakukan tapi bukan berarti hal tersebut tidak mungkin. Mengubah perkampung kumuh menjadi kampung tematik secara sederhana dapat dipahami bahwa kegiatan tersebut adalah mengubah bentuk fisik dari perkampungan yang dulunya kumuh hingga orang enggan untuk berkunjung menjadi suatu hal yang menarik minat banyak orang untuk datang dan berkunjung bahkan berwisata.

Melalui pembangunan kampung tematik akan memancing inisiatif serta partisipasi masyarakat dalam mengubah kondisi kampungnya. Dengan kreatifitas tiap masyarakat di permukimanpermukiman kumuh, ketika ingin merubah kondisi kampung yang akhirnya menyatukan pikiran dan melahirkan sebuah konsep yang akan aplikasikan guna merubah sebuah kampung kumuh.

Berangkat dari hal ini, kampung yang dulunya memiliki kumuh akibat padatnya pemikiman diwilayah tersebut sedikit demi sedikit berubah. Hal ini disampaikan pula oleh warga yang menghuni kampung tematik sebagai berikut:

“...Disini kan memang sangat padat permukimannya, terus warga disini itu kepikiran untuk jadi seperti kampung warna-warni. Nah, dari situ akhirnya warga berinisiatif buat merubah kampung. Warga gotong royong ini buat sampai jadi bagus kayak sekarang...".

Tata ruang yang ada di kampungkampung tematik yang dulunya merupakan permukiman-permukiman kumuh memang tidak dapat dirubah dikarena ketersediaan ruang yang memadai. Tapi setidaknya infrastruktur-infrastruktur lain seperti jalan-jalan kampung, gorong-gorong, serta kualitas ketahanan bangunan itu sendiri dapat diperbaiki. Hal tersebut pula disampaikan oleh warga yang menghuni kampung tematik di Kota Malang sebagai berikut:

“...Wah dulu yah tidak seperti ini. Jalanannya dulu gak sebagus ini mas, dulu kalau sudah rusak parah saja baru dibenerin kalau sekarang yah sudah beda ceritanya. Kalau sekarang untuk perawatan infrastruktur sudah dilakukan berkala biasanya satu tahun 1-2 kali. Tidak cuma itu mas, sekarang goronggorongnya juga sudah bagus kalau dulu mau gimana gorong-gorongnya dibiarin. Pengecatan juga masa perawaratannya 12 tahun sekali dan untuk cat warga sudah ada yang mensponsori. Dan semua ini dilakukan dengan inisiatif dan partisipasi langsung dari masyarkat yang tinggal disini mas. Soalnya kita juga pengen merubah keadaan mas, pengen kampung kita maju kayak kampung warna-warni..."

Dari hasil wawancara diatas dapat diperoleh gambaran bahwa dari berubahnya kampung atau permukiman kumuh menjadi kampung tematik secara langsung merubah kondisi kampungkampung kumuh yang ada. Hal tersebut terlihat mulai dari kondisi jalanan bagus serta terlihat indah karena dikelilingi tembok-tembok yang dihiasi berbagai macam gambar hasil kreatifitas warga, Atap-atap rumah yang berwarna warni sampai dengan urusan gorong-gorong pun dipikirkan sehingga tidak menyebabkan masalah dikemudian hari.

\section{Dilema Kampung Tematik dalam Kacamata Urban Resilience}

Meskipun dengan berbagai pengaruh positif yang ditimbulkan akibat dari berubahnya kampung kumuh menjadi kampung tematik namun hal tersebut tidak mengubah hal yang paling mendasar yakni trruktur dan tata bangunan yang ada di kampung-kampung tersebut. Mungkin tidak akan menjadi permasalahan apabila kampungkampung kumuh ini berada diwilayahwilayah yang tidak mengandung resiko atau pun bahaya seperti di kawasan yang landai. 
Tapi untuk kampung-kampung kumuh yang berada yang berada di kawasan sungai, mengubahnya menjadi kampung tematik memang menyelesaikan permasalahan mengenai ekonomi, sosial dan lingkungan tapi tidak dengan resiko serta bahaya yang masih tetap ada dengan struktur bangunan yang masih sama seperti sebelumnya. Setidaknya harus ada jarak yang antara bangunan dan badan sungai guna menjaga ekosistem sungai itu sendiri serta menghindarkan bahaya yang dapat timbul akibat aliran sungai yang deras. Garis batas yang dimaksud adalah garis sempadan. Penetapan garis sempadan bukan tanpa maksud dan tujuan dalam penerapannya, hal tersebut tertuang dalam Peraturan Menteri Pekerjaan Umum dan Perumahan Rakyat Republik Indonsia Tahun 2015 Tentang Penetapan Garis Sempadan Sungai dan Sempadan Danau menetapkan pada bagian pertama pasal 3 yang berbunyi sebagai berikut:

1. Penetapan garis sempadan sungai dan garis sempadan danau dimaksudkan sebagai upaya agar kegiatan perlindungan, penggunaan, dan pengendalian atas sumber daya yang ada pada sungai dan danau dapat dilaksanakan sesuai dengan tujuannya.

2. Penetapan garis sempadan sungai dan garis sempadan danau bertujuan agar:

a. Fungsi sungai dan danau tidak terganggu oleh aktifitas yang berkembang di sekitarnya;

b. Kegiatan pemanfaatan dan upaya peningkatan nilai manfaat sumber daya yang ada di sungai dan danau dapat memberikan hasil secara optimal sekaligus menjaga kelestarian fungsi sungai dan danau; dan

c. Daya rusak air sungai dan danau terhadap lingkungannya dapat dibatasi.

Mengetahui maksud dan tujuan dibuatnya garis simpadan sungai mengajadikan garis simpadan sungai merupakan hal yang sangat penting untuk diterapkan guna mendirikan bangunan di sepanjang bantaran sungai. Peraturan Menteri Pekerjaan Umum dan
Perumahan Rakyat Republik Indonsia Tahun 2015 Tentang Penetapan Garis Sempadan Sungai dan Sempadan Danau juga mengatur mengenai garis simpadan sungai dikawasan perkotaan, hal tertuang dalam pasal 5 yang berbunyi sebagai berikut: garis sempadan pada sungai tidak bertanggul di dalam kawasan perkotaan sebagaimana dimaksud dalam Pasal 4 ayat (2) huruf a, ditentukan:

1. Paling sedikit berjarak 10 (sepuluh) meter dari tepi kiri dan kanan palung sungai sepanjang alur sungai, dalam hal kedalaman sungai kurang dari atau sama dengan 3 (tiga) meter;

2. Paling sedikit berjarak 15 (lima belas) meter dari tepi kiri dan kanan palung sungai sepanjang alur sungai, dalam hal kedalaman sungai lebih dari 3 (tiga) meter sampai dengan 20 (dua puluh) meter; dan

3. Paling sedikit berjarak 30 (tiga puluh) meter dari tepi kiri dan kanan palung sungai sepanjang alur sungai, dalam hal kedalaman sungai lebih dari 20 (dua puluh) meter.

Aturan mengenai penetapan garis sempadan sungai seperti yang telah disebutkan diatas merupakan hal yang tidak dapat diganggu gugat. Karena hal ini berdampak pada manusia maupun ekosistem sungai itu sendiri. Sedangkan seperti yang dapat dilihat bahwa kawasan-kawasan kumuh yang menjadi kampung tematik di Kota Malang sebagian berada di kawasan bantaran sungai dan tidak menerapkan hal ini. Tentu hal ini merupakan sebuah pelanggaran yang berujung pada resiko yang diterima oleh masyarakat yang tinggal didalamnya. Kawasan-kawasan kampung kumuh yang kini menajadi kampung tematik di bantaran sungai yang paling nampak terlihat di Kota Malang adalah kampung wisata warna-warni, kampung 3D, serta kampung biru.

Ketiga kampung wisata yang telah disebutkan diatas yang sejak awalnya sudah berada pada kondisi serta tempat yang salah. Namun dengan segala kontradiksi yang ada, hal tersebut tetap tidak merubah keadaan infrastruktur yang ada dan justru kini kampung-kampung tersebut seolah menjelma sebagai sebuah wajah baru kepariwisataan 
Kota Malang. Tata letak infrastruktur bangunan di tepi sungai yang ditempati oleh masyarakat ini sudah seharusnya sesegera mungkin untuk ditangani karena hal ini pada akhirnya sama seperti meletakkan bom waktu pada suatu tempat yang mana dapat meledak kapan saja. Analogi ini tentu tidak berlebihan, mengingat resiko bencana yang paling mendasar yakni terkena terjangan arus air yang bisa terjadi kapan saja ketika musim penghujan dapat terdampak pada masyarakat yang tinggal kawasan-kawasan tersebut sewaktu-waktu ketika arus besar datang.

Keempat aspek yang telah disebutkan diatas telah menunjukan bahwa dampak berubahnya kampung kumuh yang enggan orang-orang untuk datang berkunjung hanya dengan merubahnya menajadi kampung tematik memberikan dampak yang luar biasa besar bukan hanya pada kondisi perkampungannya tapi juga pada masyarakat yang tinggal didalamnya. Namun, hal tersebut tetap tidak menyingkirkan resiko-resiko mendasar yang ditanggung oleh masyarakat yang tinggal didalamnya yaitu bencana alam.

\section{KESIMPULAN}

Pengaruh pembangunan kampung tematik dalam upaya menanggulangi permasalahan pembangunan wilayah perkotaan di Kota Malang memberikan dampak yang sangat positif guna penanganan mengenai pembangunan wilayah Kota Malang. Hal tersebut dapat dilihat dari bagaimana indikator world bank akan pemukiman tidak layak yang tidak bisa disematkan lagi pada kampungkampung tematik tersebut.

\section{REFERENSI}

Anonim,(2018)

https://malangkota.go.id/2016/09/05/kamp ung-warna-warni-jadi-ikon-wisata-barukota-malang/ tanggal 24 April 2018 pukul 17.00 .

Arifin, AS., (2018) Kampung Tematik DAS Brantas, Etalase Pembangunan atau Fenomena Sesaat diakses melalui. https://www.malangpost.com/netizen/opini/kampung-tematikdas-brantas-etalase-pembangunan-atau- fenomena-sesaat tanggal 24 Mei 2018 pukul 16.00.

Farida, R. (2016), Panduan Penyusunan Rencana Pencegahan dan Peningkatan Kualitas Permukiman Kumuh Perkotaan, Direktorat Pengembangan Kawasan Permukiman Kementerian Pekerjaan Umum dan Perumahan Rakyat), Kementerian Pekerjaan Umum dan Perumahan Rakyat Direktorat Jenderal Cipta Karya Jakarta.

Kamalita, ANS., (2017), Implementasi Program KOTAKU dalam Mengatasi Permukiman Kumuh di Kelurahan Sukun Kota Malang Tahun 2016 (Studi pada Dinas Perumahan dan Kawasan Permukiman), Skripsi Jurusan Ilmu Pemerintahan Fakultas Ilmu Sosial dan Politik Universitas Muhammadiyah Malang.

Nusryahbani, R., dan Pigawati, B., (2015), Kajian Karakteristik Kawasan Permukiman Kumuh di Kampung Kota (Studi Kasus: Kampung Gendekan Semarang), Jurnal Teknik PWK Vol. 4 (2): 267-281.

Peraturan Pemerintah Republik Indonesia Nomor 14 Tahun 2016 tentang Penyelenggaraan Perumahan dan Kawasan Permukiman.

Peraturan Menteri Pekerjaan Umum dan Perumahan Rakyat Republik Indonsia Tahun 2015 Tentang Penetapan Garis Sempadan Sungai dan Sempadan Danau

Peraturan Daerah Nomor 7 Tahun 2001 Tentang Rencana Tata Ruang Wilayah (RTRW) Kota Malang Tahun 2001-2011.

Pratono. 2017. Hendi Siapkan Konsep City Walk Kampung. jawa pos. diakses melalui https://www.jawapos.com/radarsemarang/r ead/2017/12/21/35037/hendi-siapkankonsep-city-walk-kampung pada tanggal 16 April 2018 pukul 15.02.

Sabaris, DSR. (2018), Pelaksanaan Program Kota Tanpa Kumuh (KOTAKU) di Jawa Tengah, Direktorat Pengembangan Kawasan Permukiman Direktorat Jenderal Cipta Karya Kementerian Pekerjaan Umum dan Perumahan Rakyat. 
Volume 70, Nomor 2, 1 Desember 2018

Sudiongko, Amggara (2016) https://www.malangtimes.com/baca/14207 /20160905/140804/kampung-warnwarnijadi-ikon-wisata-baru-kota-malang/ akses tanggal 27 November 201814.30

Surat Keputusan Wali Kota Malang Nomor 188.45/86/35.73.112/2015 tahun 2015.

UU Nomor 5 Tahun 1960 Tentang Peraturan Dasar Pokok-Pokok Agraria.

Zuhrya, A., (2017), Peranan Program Kota Tanpa Kumuh (KOTAKU) Sebagai Media Pendidikan Sosial untuk Meningkatkan Keberdayaan Ekonomi (Studi Kasus pada Masyarakat Marginal di Desa Putih Kecamatan Gampengrejo Kabupaten Kediri), Skripsi Jurusan Pendidikan Ilmu Pengetahuan Sosial Fakultas Ilmu Tarbiyah dan Keguruan Universitas Islam Negeri Maulana Malik Ibrahim Malang. 